\title{
THE SIGHTING REPORT OFJAVAN HAWK-EAGLE (Nisaetus bartelsi) IN THE AREA OF KONDANG MERAK, MALANG REGENCY, INDONESIA
}

\author{
Muhammad Ardiansyah, Haris Eka Pramudita, Heru Cahyono, Windri Hermadhiyanti, \\ Rani Arifiantari, Ana Sa'adah, Charina Ramadhani,Riri Wiyanti Retnaningtyas, \\ and Bima Diwanata \\ Malang Eyes Lapwing (MEL), Jl. Semarang 5, Malang, Indonesia 65145 \\ E-mail:hariseka31@yahoo.co.id:hermadhiyantiwindri@gmail.com
}

\begin{abstract}
Kondang Merak is one of tourism destination located in southern coast of Malang Regency. This area consists of tropical rainforest and teak forest. The birds' diversity in this area is rich, including the Javan Hawk-Eagle (Nisaetus bartelsi). This species is one of Java's endemic species that is endangered and protected by the government. This bird's population decreases due to habitat degradation, poaching, and illegal trading. This research is held to collect data about the Javan Hawk-Eagle's presence in Kondang Merak to support the conservation efforts in that region. The method used in this research is observation in several points of which the landscape conditions is estimated to match with the Javan Hawk-Eagle's habitat criteria. The Javan Hawk-Eagle was found at three different times in one of our observation area.
\end{abstract}

Key words: Nisaetus bartelsi, Kondang Merak

\section{INTRODUCTION}

Indonesia is a country with the third largest biodiversity in the world. it becomes the sanctuary of over ten percent of world's species, including birds. The bird diversity distributes all across Indonesian Archipelago ranging from Sumatra, Borneo, Java, Bali, Nusa Tenggara, Sulawesi, Papua and another smaller surrounding islands.

The existence of birds is essential to the ecosystem to maintain its balance and as the indicator of the ecosystem quality (Dono, 2013). The decerasing number of the birds can harm the ecosystem itself. Some factors can cause the number of the species to decrease, such as poaching, illegal hunting, and fish poisoning (Setyanto, 2006).

One of the indicator species is a Javan endemic species Nisaetus bartelsi or Javan Hawk-eagle. As the top-order predator in Javan natural rainforest ecosystem, it controls the population of the lower species in the food chain. Like another birds of prey, this species has such a powerful flight ability and a territory to maintain, especially during the breeding season. It relies fully on its natural habitat, the natural rainforest, to multiply and is really sensitive to any kind of disturbance such as human activities. Therefore, the Javan Hawk-eagle becomes the ultimate indicator species to determine the quality of the ecosystem.

The Javan Hawk-eagle can be found all across the Java Island. One of the sighting spots in East Java is the Kondang Merak beach which is located in the southern coast of Malang Regency. Kondang Merak is one of the tourism spots in Malang Regency that has coastal environment (Setyanto, 2006). The vegetation surrounding the beach consists of the primary rainforest and secondary forest. This ecosystem, with its species abundance including Megalaima armillaris, Splilornis cheela, Halcyon cyanoventris, Collocalia esculenta, 
Pycnonotus goiavier, Pycnonotus aurigaster, Aegitina thipia, Orthotomus sepiumand many more, is suitable for the Javan Hawk-eagle.

This research is done as one of the conservation efforts upon the Nisaetus bartelsi, concerning their essential role in Javan natural ecosystem.

\section{MATERIALS AND METHODS}

In this research, some equipments are used to identify the Javan Hawk-eagle, such as guide books and field records, location map, GPS, luxmeter to measure the abiotic components of the environment, anemometer and thermohygrometer. The data is collected along the road that leads to the Kondang Merak beach on the $4^{\text {th }}, 5^{\text {th }}$, and $6^{\text {th }}$ of May, 2013 using the exploration method and marking each coordinate with GPS. The location of Javan Hawkeagle sighting is showed in Figure 1.

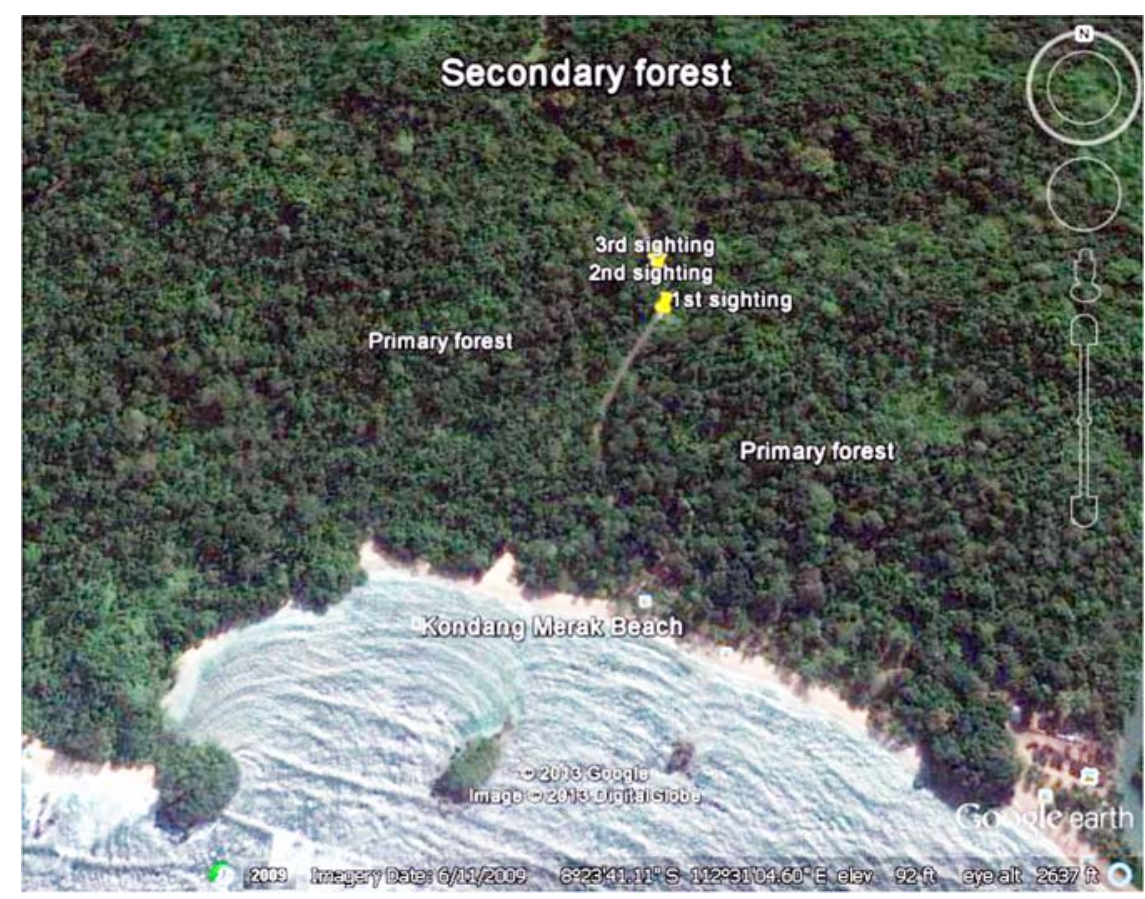

Figure 1. Research location.

\section{RESULT AND DISCUSSION}

The subject is seen in each observation. All those three observations happen in the same area in the natural coastal rainforest. The coordinate of the sighting spots are continuously presented in table 1 .

In each encounter, one similar individual is found. There is a possibility that the object is actually the same individual as it shows the same characteristics such as black crest with white color on the tip of it, brown color on the back, light brown on the upper wings, greyish tail feathers with clear white stripes on each tip. According to Sozer, et al,. (2012), those characteristics belong to the juvenile Javan Hawk-eagle. The sighting is supported by a statement by Sozer, et al. About the Javan Hawk-eagle' habitat preference, that this species prefers hills, tropical highlands or lowlands, evergreen rainforests, and unreachable places such as barren tree's peaks as nesting places and territories for one year. The Javan Hawk- 
eagle inhabits the areas ranging from the coastal areas to $2200 \mathrm{~m}$ asl, or sometimes 3000 masl. This species relies fully on the primary forest. However, the observation result shows that it also uses the secondary forest around the primary forest as breeding and hunting ground. The abiotic components measurement data is presented in the table 2.

Table 1. Cordinatee ofJavan Hawk-eagle spot.

\begin{tabular}{ccc}
\hline Sighting & Latitude & Longitude \\
\hline $1^{\text {st }}$ & $8^{\circ} 23^{\prime} 36.72$ 'S & $112^{\circ} 31^{\prime} 7.14^{\prime \prime} \mathrm{E}$ \\
$2^{\text {nd }}$ & $8^{\circ} 23^{\prime} 33.80^{\prime \prime} \mathrm{S}$ & $112^{\circ} 31.6 .444^{\prime \prime} \mathrm{E}$ \\
$3^{\text {rd }}$ & $8^{\circ} 23^{\prime} 33.60^{\prime \prime} \mathrm{S}$ & $112^{\circ} 31^{\prime} 6.43^{\prime \prime} \mathrm{E}$ \\
\hline
\end{tabular}

Table 2. The Abiotic Measurement Data

\begin{tabular}{ccccc}
\hline \multirow{2}{*}{ Spot } & \multicolumn{4}{c}{ Abiotic Factors } \\
\cline { 2 - 5 } & Wind (m/s) & Light & Temperature $\left.{ }^{\circ} \mathbf{C}\right)$ & Humidity (\%) \\
\hline I (entrance) & 0,6 & 320 & 41 & 48 \\
II & 0,7 & 500 & 32 & 60 \\
III & 0,8 & 280 & 31,8 & 61 \\
IV (sighting & 1,03 & 500 & 32 & 62 \\
spot) & & & &
\end{tabular}

\section{REFERENCES}

Dono, T. 2013. Burung Sebagai Indikator kawasan Konservasi. (Online), (http://national geographic.co.id/berita/2013/07/burung-sebagai-indikator-kawasan-konservasi), accesed August $15^{\text {th }} 2013$.

Setyanto, A. 2006. Mengamati Hewan di Ekosistem Pantai. (Online), (http://www.profauna. org/suarasatwa/id/2006/02/mengamati_hewan_di_ekosistem_pantai.html), accesed August $15^{\text {th }} 2013$.

Sozer, R. 2012. Panduan Inventarisasi Elang Jawa Nisaetus Bartelsi. Raptor Indonesia, Bogor. 